から濃度低下がみられた。しかし臨床的には被写体は均 一な吸収体ではなく骨等の高吸収体が受光部に介在する ため X 線質の変化により $60 \sim 120 \mathrm{kV}$ まで管電圧依存性 は認められず均一な濃度の写真が得られた。

\section{5. マイコンを用いた速写撮影条件の自動設定}

島津製作所医用技術部

○过 久男・柴田邦夫・中山敏夫 透視, 速写を行う X 線高電圧装置で, 使用者の知識, 経 験に基づいて，透視条件から撮影条件を自由に設定でき る装置を開発した，従来，撮影条件は透視条件から一義 的に決められていたが，今回，両者の関係を使用者が任 意に投入できるようにした，透視条件と撮影条件との関 係に被写体厚を介在させ，透視条件加間接的に被写体 厚を求め，その被写体厚に対する撮影条件を呼出すよう にした。使用者が予め撮影目的に応じて，被写体厚と撮 影条件の関係を記憶させることにより，知識，経験を撮 影条件に反映できるようにした。

\section{6。画像処理装置を用いた乳房撮影装置の試作（集団検} 診用)

愛知県がんセンター病院放射線診断部技術科

○堀田勝平 - 河合 稔 $\cdot$ 内藤光利

栗川幸義・岩根 戍

乳癌集団検診用として, I.I. と画像処理装置を用いて， 被曝線量および，画質を考慮した。ディジタルマンモラ ジオグラフィ装置を試作し，基礎および臨床実験を行っ た。試作装置のシステム概要注，(1)被射体透過 X 線を I. I. で受ける. (2) I.I. 像をTVカメラで写す. (3)画像処理装 置により画質改善を図り，TVモニタに表示する方法で ある。臨床実験を主にまとめると，(1)微小なコントラス ト変化が表示できる。(2)腫瘤陰影がでやすい. (3)被曝が 少ない. (4)撮影に熟練を要しない. (5)自動診断も可能と 思われる、今後は，自動診断装置を開発し，実用に役立 てたい.

\section{7. 胃集検における高品位 TV カメラの使用経験}

神奈川県予防医学協会

○本條八洋・萩原 明・武井恒夫

東芝メディカル 久保克彦

富士メディカルシステム 須與祥浩

われわれは最近問題になっている高品位 TVカメラ を塔載し, $100 \mathrm{~mm}$ I.I. スポット撮影とモニ夕像を併用し て読影時に提供するシステムを考え，そのシステムにお けるモニ夕精度およびTV 画像からのハードコピーに ついて幾つかの性能評価を試みた。透視画像による位置 決め精度は，胃の二重造影像が立体視できることにより
飛躍的に向上した. 臨床における TV 像, VTR 像の差は ほとんどなく，このシステムは一応の成果をおさめた。 透視再生画像からのハードコピーは, $100 \mathrm{~mm}$ I.I. スポッ トフィルムの画質にまではいたらなかった。今後これら 機器の性能改善がなされれば今回実験したシステムより 1 ステップ進んだシステムも実現可能であると思われる。

\section{座長集約}

この演題群は発表内容が多岐に分かれているため順次 各演題ごとに集約する。

演題370は霄集検装置の精度管理についての発表であ つた，検查結果についてすべて規定值以内と報告してい るが，測定方法(管電圧，管電流，自動露出等)，それに 基づく結果值について評価してほしかった。

演題371は近年病室撮影が増加している中, 移動可能な フィルムチェンジャの開発と，その仕様について第40回 総会に引き続いての発表であった。今回は病棟設置の臨 床報告があったが，病室撮影用 X 線装置に積載可能にな るならば有用な開発と考え今後の発表に期待する。

演題372は新しく開発された X 線シネ撮影用カメラに ついて，レンズの性能，カメラの振動について従来使用 (A社) カメラと比較した発表であった。性能，振動共従 来使用のカメラより優れているが，臨床写真では差が見 られずその原因はシネ撮影の場合 I. I. による影響が大 きいためと報告している。極短時間曝射を繰返し撮影す るシネ撮影の場合 X 線発生装置, $\mathrm{X}$ 線管の性能に大きく 左右されたが現在それらの開発も進み各社共優劣つけが たくなっているのが現状で，感光材料系により画質が決 定されるといっても過言でない.

演題373，374，375は自動露出機構に関連した発表で, 373席は前もって一定量の X 線を目的部位に曝射し最適 撮影条件である管電圧，管電流値をマイコンで求め撮影 する断層用自動露出機構の発表であった，今回の発表で は振角度 40 度一定であったが撮影時間が制約される断層 撮影なので, 他の軌道, 振角度についても論じられると より充実した発表になったと思う.374席は使用増感と同 じ $\mathrm{Gd}_{2} \mathrm{O}_{2} \mathrm{~S}$ をホトイマの受光部蛍光体に使用すること により写真濃度の均一化を計った報告である.375席は前 もって被写体厚に応じた管電圧をマイコンに入力し透視 管電圧より被写体厚を求め，入力データより撮影管電圧 を求めホトタイマで撮影する発表であった。 3 題いずれ の場合も関係するが自動露出機構を用いX線を制御す る時, 自動露出機構自身の持つ各特性, X 線発生装置の 特性これらを十分把握し各々が正常に動作していること が前提条件となる。 